\title{
Analysis Of Preliminary Science Literation Of Primary Teacher Education At Metro Students
}

\author{
Ika Wulandari Utamining Tias ${ }^{1}$, Amrina Izzatika $^{2}$ \\ \{ika.wulandari84@fkip.unila.ac.id ${ }^{1}$, amrina.izzatika@fkip.unila.ac.id² \\ Teacher Training and Education Faculty, Lampung of University Lampung, Indonesia ${ }^{1,2}$
}

\begin{abstract}
This paper attempted to analyze the initial scientific literacy skills of students of the PGSD FKIP University of Lampung study program. A quantitative research design with a descriptive method design was performed. The research was conducted in campus B FKIP University of Lampung. The subjects of this study were the third semester students of PGSD Campus B FKIP University of Lampung. The total of them were 51 students. A scientific literacy test was employed as the instrument. There were 20 questions on the scientific literacy test in the form of multiple choice questions. Based on the results of the research and data analysis obtained from this study, it can be concluded that the results of the analysis show that the scientific literacy skills of students who have initial literacy abilities are less than those who have not. The percentage of students who achieved initial scientific literacy skills was $45.09 \%$, while those who had not reached the level of $54.90 \%$.
\end{abstract}

Keywords: Science, literation.

\section{Introduction}

The ability of scientific literacy is a fundamental thing that must be possessed by students in facing the global era to be able to meet the needs of life in various situations. Science is a important key for the development of science and technology in order to support the competitiveness and progress of a nation so that it can compete in the international arena. Science is one of the subjects that play a important role in education because science can be a provision for students toface various challenges in the global era. Therefore, a learning method is needed that can prepare students to have good competence and to be literate in science and technology, able to think logically, critically, creatively, argue correctly, communicate and collaborate. Science literacy can be termed science literacy ability, namely the ability to understand science, communicate science (oral and write), and apply science skills to solve problems so that they have high attitudes and sensitivity to themselves and their environment in making decisions based on science considerations [1].

Increasing scientific literacy in learning can improve aspects of education, while the level of literacy in Indonesia is still lackin [2]. From the results of a study by 69 countries, the achievements of Indonesian students in science, reading, and mathematics are still ranked 62, 61 , and 63. Science literacy has been widely developed in the world of education by countries such as America, Taiwan, China, Hong Kong, Australia, Germany, and Chile, even developing countries like Nigeria [3].

According to [4], Literacy Conditions in Indonesia: - Literacy, Indonesia ranks $64^{\text {th }}$ out of $65^{\text {th }}$ countries - Student reading level. Indonesia ranks $57^{\text {th }}$ out of $65^{\text {th }}$ countries (PISA, 2010) - Reading interest index: 0.001 (every 1,000 population only one reads) - Adult literacy rate: 65.5 percent (UNESCO, 2012) In the same study, PISA also placed the reading position of 
Indonesian students at a number of 57 out of 65 countries studied. "PISA said that not a single student in Indonesia achieved literacy scores at the fifth level, only 0.4 percent of students have literacy levels at level four. The rest is below level three, even below level one.

Accordingly, according to the results of the 2012 PISA survey, Indonesia's scientific literacy score is 382 and is in the order of 63 out of 64 countries [5]. Based on a survey conducted by Trends in International Mathematics and Science Study (TIMSS) which is conducted every four years in 2007 Indonesia was ranked 35th out of 49 countries and in 2011 Indonesia was ranked 40th out of 42 countries. These results indicate that the mean score of Indonesian scientific literacy is below the mean international score and must be addressed immediately [6].

For PGSD students as prospective teachers, scientific literacy skills are an important aspect that must be mastered, because they affect the science learning process in elementary schools [7]. At this time, science learning in the 21 st century is turning into student-centered learning. Therefore, as a student as a teacher candidate must have qualified literacy skills. The success of learning is shown if they are able to understand what is being learned and can apply it in solving various problems in everyday life. Science literacy can be used as a reference for the development of science learning because science literacy is considered effective in developing science learning in the 21 st century [8].

From the results of observations in the learning process of elementary school science studies in the PGSD at FKIP Unila, it can be seen that students' science literacy skills are still base. The base science literacy can be seen from the many students who have difficulty understanding course material and difficulties in analyzing the lecture material given. The base science literacy skills of prospective teacher students will have an impact on the learning success of students in the schools they will later teach.

In addition, the base science literacy of student-teacher candidates will have an impact on the occurrence of misconceptions in students who can occur so that cognitive, affective and psychomotor learning outcomes are low. Given the very important role of the teacher in learning, a teacher must have more abilities than others to improve the quality of education. Learning carried out by the teacher must also be able to arouse students' interest in learning, so that learning becomes more meaningful. Not only teachers but prospective elementary school teachers (PGSD students) must also have better abilities so that later they can carry out their duties as teachers as well as possible [7].

According to [9], science learning is also responsible for students' science literacy. Science literacy skills reflect the readiness of citizens to respond to global challenges. Science is an important key for the development of science and technology in order to support the competitiveness and progress of a nation so that it can compete in the international arena. Science literacy can apply concepts or facts obtained in school with natural phenomena that occur in everyday life. Science literacy is a goal to be achieved by subjects belonging to science. In general, the material obtained is only partial, just memorizing and has not been applied in everyday life. In addition, generally the transfer of knowledge from educators to students regarding a concept is mostly conveyed by the abstract lecture method so that it is difficult to understand the concept.

In line with the above problems of several studies on science literacy skills, research [10] is a descriptive study that aims to identify students' science literacy abilities in ecosystem material. The research subjects were students of class VIII at Madrasah Tsanawiyah Nurul Ikhsan, Belawa Village, Lemahabang District, Cirebon Regency. The instrument used was a science literacy test developed by the author concerning the indicators contained in the development of the TOSLS (Test of Scientific Literacy Skills) test kit by [11]. The results of 
this study were the students' science literacy skills at Madrasah Tsanawiyah Nurul Ikhsan in the medium category (42.35). It is necessary to apply learning using an approach that can support to improve students' scientific literacy skills.

Furthermore, based on the results of research and data analysis [12], this type of research is used to describe the comparison between students' basic science literacy abilities, which are included in the categories: nominal, functional, conceptual, and multidimensional obtained from this study, it can be concluded that the following. (1) The initial ability of science literacy in students who are research subjects is only at two levels of the four categories of science literacy. (2) The results of the analysis show that the students' science literacy abilities for the five questions were more in the nominal category in the percentage range of $54 \%-95 \%$, a small portion in the functional category in the percentage range of $4 \%$ $9 \%$. For the conceptual and multidimensional categories, it is at a percentage of $0 \%$. (3) While some students could not provide answers to the five test numbers that were completed with a percentage range of $4 \%-45 \%$, [12].

According to research [7], what was carried out in the PGSD study program in semester II students was to see the scientific literacy abilities of PGSD students in basic science concept's courses? The science literacy skills of PGSD students have not matched expectations. There are still many PGSD students whose science literacy is still low. This is evidenced by the few who have reached science literacy. The results obtained from PGSD students, from 74 students from unit A and B that was the research subjects, namely 25 people $(52.6 .7 \%)$ from unit A and 26 people (61\%) unit B had reached science literacy and the remaining 18 people in unit $\mathrm{A}(47.3 \%)$, and 14 people in unit B $(38.8 \%)$ had not reached literacy. From this, it can be seen that the ability of PGSD students in science literacy is still low and must be improved not only in the content (content) of science, but also on the context, process, and attitude. One of the efforts to improve the science literacy of PGSD students is through the improvement of the learning process carried out, which not only emphasizes mastering concepts, but also pays attention to other aspects. Based on the research results, the researcher suggests that it is necessary to identify science literacy skills in elementary school teachers.

The importance of science literacy for everyone as a citizen, citizen and citizen of the world has been recognized in developed countries. Every citizen needs to have a level of science literacy in order to survive in nature, and in his place of work armed with the knowledge, understanding, skills and values contained therein. With the various problems that exist at the basic education level, it is necessary to increase the science literacy skills of PGSD students so that later they can develop the potential of students and can help students to improve learning outcomes and trigger students to be able to solve problems in the surrounding environment. Scientific literacy is very important for students to have as a provision to face the challenges of the 21 st century development.

The purpose of this study was to see the initial scientific literacy abilities of PGSD students in basic science concept's courses. Therefore, the researcher is interested in researching "Analysis of the Early Science Literacy Ability of PGSD Study Program Students in Elementary Science Studies." This research was conducted to categorize students' abilities in science literacy, so seven indicators were used to determine science literacy skills. The seven indicators refer to the science literacy indicator from [11]. The seven measures of science literacy indicators are (1) identifying valid science opinions (2) conducting an effective literature search (3) understanding the elements of research design and how they impact findings / conclusions (4) making graphs appropriately of the data; (5) solving problems using quantitative skills, including basic statistics; (6) understand and interpret basic statistics; (7) make inferences, predictions, and draw conclusions based on quantitative data. 
The indicator of science literacy skills developed by [11] was chosen because it is very simple, easy to implement and reflects science literacy skills. This study conducted a preliminary analysis to show the percentage of students' science literacy skills possessed by PGSD FKIP Unila students.

\section{Method}

This study applies a quantitative research design with a descriptive method design. According to [13] quantitative research is research aimed at understanding phenomena naturally, openly, without any engineering controlling variables, obtained from the perspective of participants with interactive strategies. The data processing technique used is adjusted to the data obtained, which includes several stages, namely:

Analysis Of Preliminary Science Literation Of PGSD Metro Students.

a. Determination of the minimal criteria for determined whether the PGSD student has reached science literacy or not. In this study, the minimal limit to be said to have reached science literacy is 65 . So PGSD students who score $\geq 65$ are declared to have reached science literacy, and those who score $<65$ are declared not to have reached science literacy.

b. The scoring for each question, where the maximum score for each question is 1 , so the maximum score is 20 and is converted to 100.

c. Converting the scores obtained into values, using equations:

$$
\text { Score }=\frac{\text { Score Obatined }}{\text { Maximum Score }} \times 100 \%
$$

d. Determine the research subjects in groups who have reached natural science literacy and those who have not reached science literacy.

e. After processing the data, it is then analyzed the data for further analysis and description.

\section{Results and discussion}

\subsection{Results}

The results of the study along with a discussion of the basic science literacy abilities of PGSD study program students. The data and information processed are in the form of a science literacy basic ability test. The initial stage of the research was the preparation of a scientific literacy ability test and used indicators adapted from [11]. 
Analyze of the Average Score of each Indicator of Science Literacy. Increasing science literacy can be grouped by each indicator, namely: (1) Identifying valid science opinions (for example, opinions / theories to support hypotheses; (2) Performing effective literature searches (for example, example evaluating the validity of sources and distinguishing between types of sources); (2) 3) Understand the elements in the research design; (4) Make graphs appropriately from the data, (5) Solve problems using quantitative skills, including basic statistics (for example, example calculating average, probability, percentage, frequency); (6) Understanding and interpret basic statistics (interpret errors, understand the need for statistical analysis); (7) Make inferences, predictions, and draw conclusions based on quantitative data. The mean value of the seven indicators of scientific literacy is shown in Figure 1.

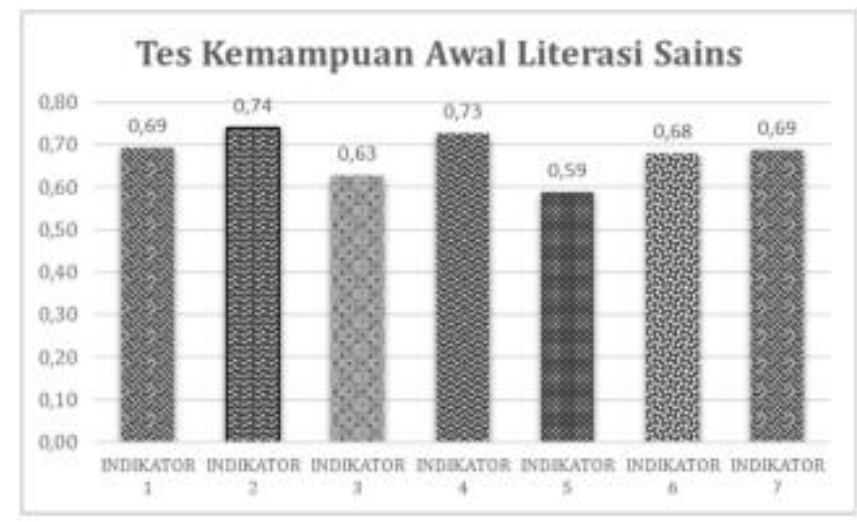

Figure 1. Bar Chart of Science Literacy for Each Indicator

Based on Figure 4, it can be seen that the mean value for the first indicator's science literacy is 0.69 . The average value of science literacy for the second indicator is 0.74 . The average scores of scientific literacy in the third to seventh indicators were $0.63,0.73,0.59,0.68$, and 0.69 , respectively. From the diagram, it is found that the second indicator has the highest average, while the lowest is on indicator five.

Student Initial Ability Value. Data on the acquisition of student scores, determining the least criteria for determining whether PGSD students have reached science literacy or not. In this study, the minimal limit to be said to have reached scientific literacy is 65 . So PGSD students who score $\geq 65$ are declared to have reached science literacy, and those who score $<65$ are declared not to have reached science literacy. Table 1 describes the percentage of students' initial scientific literacy ability calculated from the value after working on the questions. Table 1. Rate Percentage of Students' Initial Science Literacy Ability.

Table 1. shows that students who have basic literacy skills are less than those who have not. The percentage of students who achieved basic scientific literacy skills was $45.09 \%$, while those who had not reached were $54.90 \%$.

\begin{tabular}{cccc}
\hline \multirow{2}{*}{ No } & \multirow{2}{*}{ Number of Students (people) } & \multicolumn{2}{c}{ Percentage of Students' Initial Science Literacy Ability } \\
\cline { 2 - 4 } & 51 & $5 \mathbf{6 5}$ & $\leq \mathbf{6 5}$ \\
\hline 1 & $51.90 \%$ & $45.09 \%$ \\
\hline
\end{tabular}


Discussion. From the results of the study, it was found that the average result of the fifth indicator, namely solving problems using quantitative skills, including basic statistics, is the inability of students to explain science phenomena and to use science evidence. It shows that students have not been able to solve problems scientifically, as well as communicate or save results. Save the results of the experiments conducted in writing. These results indicate that students in the process of learning science or science are still not implemented according to the nature of science, namely products, processes and attitudes.

Overall, students' science literacy skills have low science literacy skills. This is shown from the results of the students' scientific literacy test questions that can only determine the problem but cannot provide a science explanation. Several factors cause, among others, students who are not used to completing tests of science literacy skills or problems related to science process skills, which are the main part of scientific literacy. Science literacy related to science material pays attention to cognitive and effective aspects. The cognitive aspect includes knowledge and its capacity to use knowledge effectively and involves cognitive processes that are characteristic of science in the personal, social and global fields. The affective aspect deals with problems that can be solved by scientific knowledge and shapes students who are able to take decisions at present and in the future.

According to [11], science literacy ability is defined as a person's ability to distinguish science facts from a variety of information, recognize and analyze the use of science investigation methods and the ability to organize, analyze, interpret quantitative data and science information.

Based on the results of the analysis of students' basic literacy abilities, it shows that students who have science literacy skills are smaller than those who do not. The percentage of students who achieved basic scientific literacy skills was $45.09 \%$, while those who had not reached were $54.90 \%$. There needs to be learning that can train science process skills so that students are accustomed to doing things related to activities, including: formulating experiment skills, questioning skills, hypothesis formulation skills, experimental planning skills, conclusion drawing skills, and predictive skills to solve problems.

The factors causing the lack of students' initial abilities in science literacy are: students rarely do practicum activities. Students spend a lot of time with knowledge on the aspect of memorization, which proves that students have difficulty applying proper science knowledge and explaining potential implications with society and then communicating them. This is supported by research [14] that teacher learning strategies greatly affect the level of science literacy. Students prefer it when lecturers use demonstration strategies or invite students to experiment when compared to remember and applying scientific knowledge. According to [15] the solutions that can be offered to improve science literacy skills are the need for learning through experiments, Problem-Based Learning (PBL) strategies and learning cycle learning models. This is in line with [16], so science literacy skills can improve properly. Teachers are encouraged to introduce and teach material using various strategies that have a scientific literacy perspective, including teaching material through experiments that can stimulate higher-order thinking and are contextual in nature.

Science literacy skills measured in this study include the ability to explain science phenomena, evaluate and design science investigations, interpret logical data and evidence (LS3). The score distribution shows that the most correct answer samples are in the ability to interpret data and science evidence, secondly on the ability to explain scientific phenomena, and finally evaluate and design systematic investigations. Perform practicum activities; (2) Students do not understand the terms in some science investigation activities such 
as independent variables and dependent variables; (3) Learners spend more time with science that promotes memorization [17].

In addition, according to [18]. The achievement of more optimal science literacy skills can be realized with proper handling, such as characteristics and potential of students require special attention, developments of teaching materials and arrangement of instruments are suitable for student conditions. Well-managed learning activities and learning strategies are right on target? For examples with by developing modules that can optimally support students' science literacy. In line with this, according to [19] "Scientific literacy is straight correlated with building a new generation of stronger science minds that can effectively communicate research science to the overall public." Science literacy is clearly correlated with building brand new generations that have strong science thoughts and attitudes that can productively communicate knowledge and research results to the general public. A person who has science literacy is a person who uses scientific concepts, has science process skills to assess daily decisions when dealing with other people, society and their environment, including social and economic development [10].

Analysis Of Preliminary Science Literation Of Pgsd Metro Students. From the results of research conducted that the scientific literacy ability of PGSD FKIP Unila students from the indicator [11] analyzed there was no difference between indicators 1-7. The analysis of each indicator shows that the average literacy ability of students is not much different in answering questions related to literacy. This initial analysis of scientific literacy skills is a benchmark for lecturers in delivering science material with appropriate learning strategies. The literacy skills possessed by students will be a provision to use them in the learning process at school as educators in the process of explaining the nature of science as a product, process and attitude and relating the material to everyday life.

\section{Conclusion}

Students' science literacy ability towards science study material is still low. Based on the results of research and data analysis obtained from this study, it can be concluded that the results of the analysis show that the science literacy skills of students who have basic literacy abilities are less than those who have not. The percentage of students who achieved basic science literacy skills was $45.09 \%$, while those who had not reached were $54.90 \%$. The mean value for the first indicator's science literacy ability is 0.69 . The average value of scientific literacy for the second indicator is 0.74 . The mean scores of science literacy in the third to seventh indicators were $0.63,0.73,0.59,0.68$, and 0.69 , respectively.

\section{References}

[1] Yuliati, Y. 2017. LITERASI SAINS DALAM PEMBELAJARAN IPA. J. Cakrawala Pendas. doi: 10.31949/jcp.v3i2.592.

[2] Pertiwi, U. D. and Rusyda Firdausi, U. Y. 2019. UPAYA MENINGKATKAN LITERASI SAINS MELALUI PEMBELAJARAN BERBASIS ETNOSAINS. Indones. J. Nat. Sci. Educ. doi: 10.31002/nse.v2i1.476.

[3] D. P. Ojimba, 2013. Scientific and technological literacy in Africa: Issues, problemas and prospects' dimensions (IPP), Educ. Res. Int.

[4] Yulaningsih and Aminah, N. A. 2014. Literasi Indonesia Sangat Rendah. Republika Online. Republika, 
[5] OECD. 2016. Result From PISA 201. Ctry. Note.

[6] Ina A. A., Mullis,V.S., Martin, Michael O., Foy, Pierre. 2012. Timss 2011 International Results in Mathematics.

[7] Fazilla, S. 2016. Kemampuan Literasi Sains Mahasiswa Pgsd Pada Mata Kuliah Konsep Dasar Sains. None.

[8] Pertiwi, U. D., Atanti, R. D., and Ismawati, R. 2018. PENTINGNYA LITERASI SAINS PADA PEMBELAJARAN IPA SMP ABAD 21. Indones. J. Nat. Sci. Educ. doi: 10.31002/nse.v1i1.173.

[9] Liliasari, 2011. Membangun masyarakat melek sains berkarakter bangsa melalui pembelajaran.

[10] Arohman, M. and Priyandoko, D. 2016. Kemampuan Literasi Sains Siswa pada Pembelajaran Ekosistem, Jurnal.Uns.Ac.Id.

[11] Gormally, C., Brickman, P., and Lut, M. 2012. Developing a test of scientific literacy skills (TOSLS): Measuring undergraduates' evaluation of scientific information and arguments. CBE Life Sci. Educ. doi: 10.1187/cbe.12-03-0026.

[12] Odja, A. H. and Payu, C. S. 2014. Analisis kemampuan awal literasi sains siswa pada konsep IPA.

[13] Sukmadinata, N. S. 2011. Metodologi Penelitian Pendidikan. Bandung: PT Remaja Rosdakarya,

[14] Ekohariadi. 2009. Faktor-faktor Yang Mempengaruhi Literasi Sains Siswa Indonesia Berusia 15 Tahun. J. Pendidik. Dasar.

[15] Winata, A., Cacik, S. and I. S. R. W. 2017. ANALISIS KEMAMPUAN AWAL LITERASI SAINS MAHASISWA PADA KONSEP IPA. Educ. Hum. Dev. J. doi: 10.33086/ehdj.v1i1.291.

[16] Diana, S., Rachmatulloh, A. and Rahmawati, E. S. 2015. Profil Kemampuan Literasi Sains Siswa SMA berdasarkan Instrumen Scientific Literacy Assesments (SLA). Pros. Semin. Nas. XII Pendidik. Biol. FKIP UNS.

[17] Rusilowati, A., Kurniawati, L., Nugroho, S. E., and A. Widiyatmoko, 2016. Developing an instrument of scientific literacy asessment on the cycle theme. Int. J. Environ. Sci. Educ.

[18] Safitri, Y. and Mayasari, T. 2018. Analisis Tingkat Kemampuan Awal Siswa SMP/MTS dalam Berliterasi Sains pada Konsep IPA. Pros. Semin. Nas. Quantum.

[19] Treacy, D. J. and Kosinski-Collins, M. S. 2011. Using the Writing and Revising of Journal Articles to Increase Science Literacy and Understanding in a Large Introductory Biology Laboratory Course. Atlas J. Sci. Educ. doi: 10.5147/ajse.2011.0032. 